\title{
Phenomenologies of Environment and Place ${ }^{1}$
}

David Seamon

Kansas State University

\section{A Phenomenology of Lifeworld and Place}

A key to a phenomenology of community and locality is, the lifeworld - the taken-for-granted pattern and context of everyday living through which the person conducts his or her day-to-day life without having to make it an object of conscious attention (Seamon, 1979). Immersed in their daily world of cares and concerns, people normally do not consider the lifeworld; it is concealed as a phenomenon. A phenomenological approach works to unmask the lifeworld's concealment, bringing its aspects and qualities to explicit scholarly attention. The geographer and architect, working phenomenologically, are concerned with the geographical, environmental, and architectural dimensions of the lifeworld and focus on such themes as sense of place, at-homeness, and environmental experience and behavior. Two key phenomenological notions important here are outsideness and insideness, which are especially significant because they set up an immediate relationship of fusion between person and world. Buttimer (1977) emphasizes that much conventional work on locality and place emphasizes the perspective of outsider-i.e., the researcher assumes "the role of detached observer encouraged by conventional definitions of scientific method to take a so-called 'objective' stance on the data which he perceives" (p. 150). In this perspective, the researcher views region and place largely in terms of tangible artifacts and flows: for example, land use, housing types, activity patterns, political linkages, or number of services. For planning and policy, the assumption is that manipulation of the material environment will lead to a more livable place or region. This point of view dominates much of the so-called "applied" environmental architectural and planning research today. The weakness of the outsider's view is that the researcher interprets region in his or her own presupposed terms and "is therefore inevitably drawn toward finding in places what he or she intends to find in them " (Buttimer, 1980, p. 171).

Buttimer argues that the need is to understand locality and region in terms of the insider, the person who normally lives in and uses the place or region. The insider's world is grounded in the everyday experience of living in a particular environment; it involves processes 
and events normally unnoticed and unquestioned. The insider generally takes his or her place and region for granted, rarely conceiving of them as explicit entities that might be made objects of directed attention. In relation to planning and policy, says Buttimer, the trap for the insider is that "one lives in places and may be so immersed in the particulars of everyday life and action that he or she may see no point in questioning the taken-for-granted or in seeing home in its wider spatial or social context" (Buttimer, 1980, pp. 171-72).

Buttimer concludes that a major need in terms of community and locality is to promote a reflexive understanding for both insider and outsider. This self-conscious awareness would serve two functions: first, help the insider to see his place as an explicit entity with links to a larger socio-economic milieu; second, help the outsider to supplement his language of material patterns and processes with the experiential dynamics of place. The main task, in other words, is pedagogical and involves "a calling to conscious awareness those taken-for-granted ideas and practices within one's own personal world and then to reach beyond them toward a more reasonable and mutually respectful dialogue between those who wish to live in places and those who wish to plan for them" (Buttimer, 1980, p. 170).

The difficult question is how such sensitization and dialogue can proceed practically. The idea of congruence between insider and outsider is attractive theoretically, but practically it often seems impossible. The first need is a framework of understanding that portrays outsideness and insideness, especially the latter, in terms that individuals, both experts and laypersons, can readily grasp. Work in conventional environmental psychology and behavioral geography has, of course, attempted to clarify the nature of the insider's world (e.g., Gold, 1980). The phenomenological criticism of this work is its grounding in a conventional positivist approach (Samuels, 1971; Seamon, 1979). The result has often been concepts and theories-for example, cognitive mapping, territoriality, environmental preferences-which more often appear to be contrived intellectual constructs than genuine behavioral and experimental structures residing in the lifeworld. In contrast, a phenomenological approach to insideness and outsideness attempts to illuminate these worlds as they are in their own fashion in a way that will help insiders and outsiders to understand patterns and dynamics which otherwise might go unnoticed.

One important author in this regard is Relph (1976), who explores the nature of space and place phenomenologically and extends Buttimer's presentation of outsideness and insideness by viewing them as ends of a continuum along which can be identified various modes of place experience. Relph's key argument is that places have 
meaning in direct proportion to the degree that one feels inside that place-i.e., "here" rather than "there," enclosed rather than exposed, secure rather than threatened. Next, one can speak of varying degrees of insideness: for example, existential insideness, the deepest experience of place and involving an unself-conscious immersion in place; or empathetic insideness, a situation where a person who is an outsider in terms of place works through concern, interest, and empathy to understand that place and comes to know its essential meaning and structure. On the other hand, one can feel outside place: for example, existential outsideness, a sense of alienation and homelessness; or objective outsideness, the intentional separating of person from place in order to study it selectively in terms of one particular attribute or activity.

Though clearly incipient and not inclusive, Relph's insideoutsideness continuum is an important beginning for providing a self-consciousness presentation of place experience which applies to particular places yet extends beyond them to help people understand their environmental dealings in more general, reflexive terms. Relph's continuum sensitizes researchers to different modes of place experience, helping them to realize that the same place may foster considerably different modes of insideness and outsideness for different individuals and groups. Consider, for example, the use of this continuum in the classroom. Students are asked to select a mode of insideness and outsideness with which they feel familiar and to describe it in writing. A Nigerian student depicts the strong existential outsideness he felt when first arriving in America, while a woman who grew up in a small Kansas town pictures the intense sense of existential insideness she knew there. Yet another student, formerly a travelling salesman, speaks about the incidental outsideness he felt passing through places that were little more than backgrounds for his primary aim of selling. Next, students are asked to assemble in small groups and describe to each other their various accounts. The result is a self-conscious awareness of experiences and places which before were unreflected upon and therefore unnoticed.

Buttimer suggests that ultimately it is the empathetic insider who is best able to mediate between people who live in places and people who wish to plan for those places. The empathetic insider attempts to understand place and region as they are in their own fashion and therefore takes the time and effort to grasp the insider's life and to render an accurate account. An important contribution that the phenomenological perspective can offer the student wishing to become an empathetic insider is a set of concepts authentically portraying essential structures of place and lifeworld. Relph's inside-outside continuum is successful in this regard, and other reflexive research offers valuable additional themes (e.g., Tuan, 1974, 
1977, 1979; Seamon, 1981; Norberg-Schulz, 1980; Relph, 1981). For example, my research (Seamon, 1979; Seamon \& Nordin, 1980), drawing in part from Merleau-Ponty, has explored the role of body as subject in place experience and details such extended bodily behaviors as "body ballets" and "time-space routines." Further, I have argued that individual bodily behaviors can interact in a supportive physical environment to create "place ballets"-a regularity of individual habits and routines in terms of space, as in an outdoor marketplace, local diner, or street neighborhood. Crucial real-world studies here include Jacobs' (1961) examination of urban street life and diversity, Whyte's (1980) analysis of successful city parks and plazas, Newman's (1980) architectural efforts to create urban residential designs that promote a sense of community consciousness and responsibility, and Fathy's (1973) attempt to construct housing and villages for displaced Egyptian peasants. Though not directly phenomenological, these works show an insightful ability to see and understand environment and community experientially. They give clues as to what, in practical, day-to-day terms, an authentic phenomenology of the person-world relationship must be.

\section{A Phenomenology of Physical Environment and Landscape}

Phenomenology also offers valuable insight into the physical, ecological, and energy dimensions of locality, community, and place. An ecological phenomenology of physical environment and landscape asks how people-in-places work experientially and behaviorally as ecological units. A major concern is whether stability and rootedness in place promote a more efficient use of energy, space, and environment than today's predominant-place relationship emphasizing spatial mobility and the frequent disruption and destruction of unique places (Relph, 1976). An existential phenomenology of physical environment and landscape asks a complementary question: what are the existential advantages of place-bound lifeworlds? Do they, for example, facilitate in better measure than a physically dispersed lifeworld such qualities as at-homeness, community participation, or care and concern for the environment?

The overriding questions for both the ecological and existential dimensions of a phenomenological focus are what, ecologically and existentially, is a suitable balance between home and surrounding places, between one's own region and the larger world? Has Western society presently extended itself too far at the expense of home? Are Western people presently too mobile at the expense of community stability and continuity? How can technological devices such as transportation, cybernetics, and mass communication be used to serve home and local region as well as places beyond them? What technologies promote dwelling and a sense of region rather than placelessness, homelessness, and the destruction of regional identity? 
It is in relation to questions like these that a phenomenology of landscape becomes significant, for a major question is how the physical environment contributes to a sense of region and place. The ancient Romans held that all natural places possessed a genius loci, a spirit of place. This spirit, it was believed, gave life to people and places and determined their character or essence. A phenomenology of landscape gives the notion of genius loci renewed academic attention. It asks how the qualities of the natural environment meet together in place to create the place's special character and style. One important first attempt here is Norberg-Schulz's (1980), which establishes phenomenologically a four-fold typology of natural places grounded in such qualities as spatial character, light, and daily and seasonal rhythms.

First, Norberg-Schulz describes the romantic landscape, an environment of change, variety, and detail best illustrated by the forests of Scandinavia; second, the cosmic landscape, an environment of monotony and massive expanse, best exemplified by the desert; third, the classical landscape, an environment balancing variety and continuity, best illustrated by the Greek landscape; and, fourth, the complex landscape, a blend of the first three and ultimately best representing most actual places, which generally are never pure but mixed in their natural expression. In short, Norberg-Schulz's aim is to identify how atmosphere, water, land, and life meet in location to generate a particular style of physical environment, natural place, and region.

\section{Conclusion}

If asked to summarize the underlying thrust in the work just described, one might respond that it is the creative effort to reunite person and world through the existential structure of place grounded spatially and environmentally. People are not separate from their worlds; rather, they are immersed through an invisible net of bodily, emotional, and environmental ties. Place, of course, is only one phenomenological vantage point from which to clarify the person-world relationship, but it is a crucial starting point for the human sciences, since people are physical, bodily beings who must establish and identify themselves spatially and environmentally. At the same time, this physical grounding probably has links with other dimensions of human existence-take, for example, the social lifeworld. The phenomenological Schutz (1962) writes that "all the other manifold social relationships are derived from the originary experiencing of the totality of the other's self in the community of time and space. Any theoretical analysis of the notion of environment . . . would have to start from the face-to-face relations as a basic structure of the world of daily life" (p. 221). This statement suggests that the geographical lifeworld, especially its spatial di- 
mension of informal, face-to-face interaction housed in bodysubject, provides the foundation for the social lifeworld. More than likely, a focus on this theme is where themes in social geography, environmental psychology, sociology, and communications studies meet.

\section{Notes}

1. Paper prepared for the Second Annual Human Science Research Conference, Duquesne University, Pittsburgh, PA, 18-20 May, 1983.

\section{References}

Buttimer, A. (1977). 'Insiders,' 'Outsiders,' and the geography of regional life. In A. Kulinski, O. Kultalahti, \& B. Koshioho (Eds.), Regional dynamics of socioeconomic change (pp. 155-178). Tampera, Finland: Finnpublishers.

Buttimer, A. (1980). Home, reach, and a sense of place. In A. Buttimer, \& D. Seamon (Eds.), The human experience of space and place (pp. 166187). London: Croom Helm.

Fathy, H. (1973). Architecture for the poor. Chicago: University of Chicago.

Gold, J. (1980). An introduction to behavioral geography. Oxford: University of Oxford.

Jacobs, J. (1961). The death and life of great American cities. New York: Vintage.

Newman, O. (1980). Community of interest. New York: Doubleday.

Norberg-Schulz, C. (1980). Genius loci: Toward a phenomenology of architecture. New York: Rizzoli.

Relph, E. (1976). Place and placelessness. London: Pion.

Relph, E. (1981). Rational landscapes and humanistic geography. London: Croom Helm.

Samuels, M. (1971). Science and geography: An existential appraisal. Unpublished doctoral dissertation, University of Washington, Seattle.

Schutz, A. (1962). Collected papers, Vol. 1. The Hague: Martinus Nighoff.

Seamon, D. (1979). A geography of the lifeworld. New York: St. Martin's.

Seamon, D. (1981). Newcomers, existential outsiders and insiders: Their portrayal in two books by Doris Lessing. In D. C. D. Pocock (Ed.), Humanistic geography and literature (pp. 85-100). London: Cross Helm.

Seamon, D. (1982). The phenomenological contribution to environmental psychology. Journal of Environmental Psychology, 2, 119-140.

Seamon, D., \& Nordin, C. (1980). Market place as place ballet: A Swedish example. Landscape, 24, 35-41.

Tuan, Y. (1974). Topophilia. Englewood Cliffs, NJ: Prentice-Hall.

Tuan, Y. (1977). Space and place: The perspective of experience. Minneapolis: University of Minnesota Press.

Tuan, Y. (1979). Landscape of fear. New York: Pantheon.

Whyte, W. (1980). The social life of small urban spaces. Washington, DC: The Conservation Foundation. 